\title{
AXONAL DEGENERATION AND NEUROPATHY TARGET ESTERASE*
}

\author{
Paul GLYNN \\ MRC Toxicology Unit, University of Leicester, United Kingdom \\ Received in January 2007 \\ Accepted in February 2007
}

\begin{abstract}
This brief review summarises recent observations which suggest a possible mechanism for organophosphateinduced delayed neuropathy (OPIDN). Neuropathy target esterase (NTE) has been shown to deacylate endoplasmic reticulum (ER) membrane phosphatidylcholine (PtdCho). Raised levels of PtdCho are present in the brains of swiss cheese/NTE mutant Drosophila together with abnormal membrane structures, axonal and dendritic degeneration and neural cell loss. Similar vacuolated pathology is found in the brains of mice with brain-specific deletion of the NTE gene and, in old age, these mice show clinical and histopathological features of neuropathy resembling those in wild-type mice chronically dosed with tri-ortho-cresylphosphate. It is suggested that OPIDN results from the loss of NTE's phospholipase activity which in turn causes ER malfunction and perturbation of axonal transport and glial-axonal interactions.
\end{abstract}

KEY WORDS: brain, carbamate, endoplasmic reticulum, organophosphate, phospholipid

During the $20^{\text {th }}$ century, thousands of people were paralysed by accidental ingestion of tri-orthocresylphosphate (TOCP). The same paralysis was present in rare cases of poisoning by some organophosphorus (OP) insecticides. OP-induced delayed neuropathy (OPIDN) has been studied experimentally in chickens, and features a latent period of at least one week before the onset of progressive hind limb ataxia and paralysis accompanied by distal degeneration of long nerves in the spinal cord and legs $(1,2)$. Neuropathic OPs inhibit the ability of brain homogenates to catalyse hydrolysis of an artificial ester substrate and this enzyme activity is called NTE $(3,4)$. However, the events linking NTE to axon degeneration were enigmatic until molecular cloning of NTE (5) allowed new experimental approaches.

\section{The biochemical function of NTE}

Studies in mammalian cell lines and yeast have shown that NTE is anchored to the cytoplasmic face of the endoplasmic reticulum (ER) where it catalyses the deacylation of phosphatidylcholine (PtdCho) to glycerophosphocholine $(6,7)$ (Figure 1). PtdCho comprises up to $50 \%$ of the phospholipid content of eukaryotic cell membranes and thus NTE plays a major role in membrane homeostasis. PtdCho accumulates in, and NTE activity is absent from, the brains of swiss cheese mutant Drosophila and this is accompanied by membrane abnormalities, axonal/dendrite degeneration and brain vacuolation (8). Likewise, in mice with brainspecific NTE deletion, prominent vacuolation of the hippocampus and thalamus is evident between 2 to 5 months of age (9).

\footnotetext{
* Partly presented at the EUROTOX 2006/6 CTDC Congress - Symposium on Molecular Mechanisms of Organophosphates, Cavtat, Croatia, 20-24 September 2006.
} 


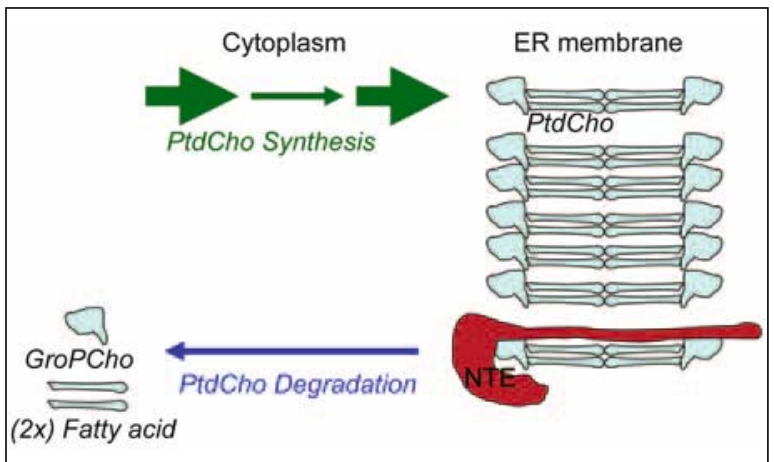

Figure 1 NTE deacylates endoplasmic reticulum-associated phosphatidylcholine. In this biosynthetic pathway, choline is converted to phosphocholine, then CDP-choline which is finally reacted with diacylglycerol, forming phosphatidylcholine (PtdCho) at the cytoplasmic face of the ER membrane. NTE is tethered in this location by a transmembrane segment and deacylates PtdCho to form soluble products, free fatty acids (FFA) and glycerophosphocholine (GroPCho). For more details see ref. (7).

\section{Species susceptibility to OPIDN}

In large animals (humans, cattle, cats, chickens) a single dose of neuropathic OP causes ataxia and paralysis within 1 to 3 weeks. By contrast, rodents, and particularly mice, are refractory to OPIDN. A few swollen axons in the brain stem of mice were detected three weeks after a single dose of TOCP, but no clinical signs or axonal degeneration (10). However, dosing mice with TOCP daily for 9 months induced axonal degeneration and hind-limb paralysis (11). Finally, brain-specific NTE knock-out mice exhibit progressive axonal degeneration and hind-limb ataxia between 6 to 12 months of age (Read et al, unpublished).

\section{Non-neuropathic inhibitors of NTE}

Carbamates such as pyridostigmine have been used to protect humans and animals from imminent exposure to OP nerve agents. The basis for this protection is that carbamylation of acetylcholinesterase (AChE) prevents its reaction with the OP during a critical period before the available concentration of the latter falls to non-toxic levels; during this period, continuous reactivation and re-inhibition of $\mathrm{AChE}$ by the carbamate must permit sufficient activity to prevent toxic accumulation of acetylcholine (4). Similarly, predosing chickens with certain carbamates can protect against induction of OPIDN by a subsequent dose of neuropathic OP; this protection lasts as long as the half-life of carbamylated NTE (about 12 h) (12).

Much of the enigma surrounding the pathogenesis of OPIDN stems from the finding that compounds such as phenylmethanesulfonylfluoride (PMSF) and certain organophosphinates can also protect against OPIDN, even though they themselves appear to inhibit NTE for several days. Furthermore, neuropathic OPs undergo an aging reaction in which one of the alkyl/aryl groups is rapidly expelled from organophosphorylated NTE, leaving a negatively-charged adduct. This process renders the enzyme far more resistant to reactivation. However, it has been argued that the generation of negatively-charged adduct, rather than inhibition of NTE's catalytic activity, is responsible for initiating OPIDN $(13,14)$ and that aging may induce a toxic gain of function in NTE (15).

On the other hand, sequential dosing with large amounts of a carbamate followed by PMSF does induce (mild) neuropathy. From this, it has been suggested that aging is not essential for OPIDN and that NTE inhibitors may have varying degrees of neuropathic efficacy, analogous to full and partial receptor agonists (16).

\section{Inactivation of NTE initiates OPIDN}

OP inhibition of NTE will, at least temporarily, disrupt ER phospholipid homeostasis which may cause general malfunction of the ER. Since this organelle is the starting point for all secretory transport in eukaryotic cells, both axonal transport and interaction between the axon and supporting glial cells will be perturbed. Inhibition of retrograde axonal transport has been demonstrated in OP-dosed chickens before the onset of ataxia (17). Abnormal glial-axonal/neuronal interaction is the earliest detected pathological change in the brains of swiss cheese flies (18). Distal parts of long axons may be most sensitive to this perturbation, as they are the farthest from the sources of energy and materials supplied by the neuronal cell body (Fig 2). The fact

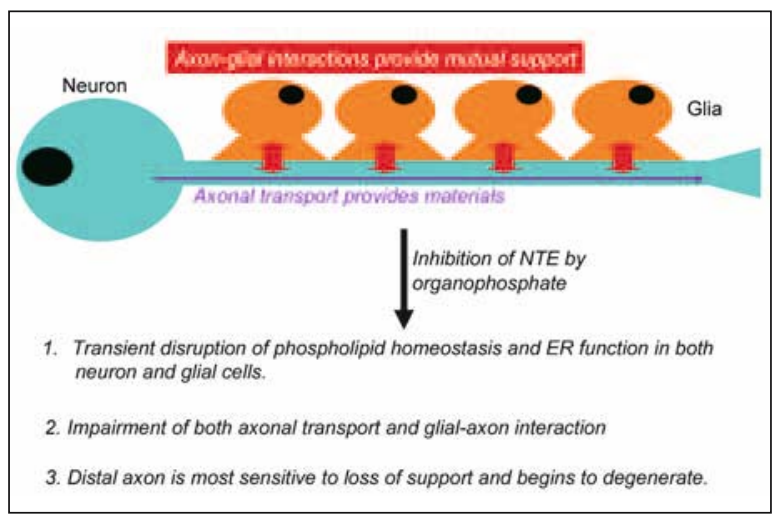

Figure 2 Long axons are hypervulnerable to loss of NTE function 
that genetic knock-out of NTE and chronic TOCP dosing induce a similar neuropathic syndrome in mice is compelling evidence that the OP is indeed acting by inactivating NTE rather than by inducing a toxic gain of function.

\section{Acknowledgements}

I thank the MRC for supporting work on NTE at the Toxicology Unit.

\section{REFERENCES}

1. Cavanagh JB. The significance of the "dying back" process in experimental and human neurological disease. Int Rev Exp Pathol 1964;3:219-67.

2. Ehrich M, Jortner BS. Organophosphorus-induced delayed neuropathy. In: Krieger R, editor. Handbook of Pesticide Toxicology. Vol. 2. $2^{\text {nd }}$ ed. San Diego (CA): Academic Press; 2001. p. 987-1012.

3. Johnson MK. The target for initiation of delayed neurotoxicity by organophosphorus esters: biochemical studies and toxicological applications. Rev Biochem Toxciol 1982;4:141-212.

4. Lotti M. Organophosphorus compounds. In: Spencer PS, Schaumburg HH, Ludolph AC, editors. Experimental and Clinical Neurotoxicology. $2^{\text {nd }}$ ed. New York (USA): Oxford University Press; 2000. p. 897-925.

5. Lush MJ, Li Y, Read DJ, Willis AC, Glynn P. Neuropathy target esterase and a homologous Drosophila neurodegeneration associated mutant protein contain a novel domain conserved from bacteria to man. Biochem J 1998;332:1-4.

6. Li Y, Dinsdale D, Glynn P. Protein domains, catalytic activity and subcellular distribution of neuropathy target esterase in mammalian cells. J Biol Chem 2003;278:8820-5.

7. Zaccheo O, Dinsdale D, Meacock PA, Glynn P. Neuropathy target esterase and its yeast homologue degrade phosphatidylcholine to glycerophosphocholine in living cells. J Biol Chem 2004;279:24024-33.
8. Mühlig-Versen M, Bettencourt da Cruz A, Tschäpe J-A, Moser M, Büttner R, Athenstaedt K, Glynn P, Kretzschmar D. Loss of Swiss cheese/Neuropathy target esterase activity causes disruption of phosphatidylcholine homeostasis and neuronal and glial death in adult Drosophila. J Neurosci 2005;25:2865-73.

9. Akassoglou K, Malester B, Xu J, Tessarollo L, Rosenbluth $\mathrm{J}$, Chao M. Brain-specific deletion of neuropathy target esterase/swiss cheese results in neurodegeneration. Proc Natl Acad Sci (USA) 2004;101:5075-80.

10. Veronesi B, Padilla S, Blackmon K, Pope C. Murine susceptibility to organophosphorus-induced delayed neuropathy. Toxciol Appl Pharmacol 1991;107:31124.

11. Lapadula DM, Patton SE, Campbell GA, Abou-Donia $M B$. Characterisation of delayed neurotoxicity in the mouse following chronic oral administration of tri-ocresyl phosphate Toxicol Appl Pharmacol 1985;79:8390.

12. Johnson MK, Lauwerys R. Protection by some carbamates against the delayed neurotoxic effects of diisopropyl phosphorofluoridate. Nature 1969;222:10667.

13. Johnson MK. The primary biochemical lesion leading to the delayed neurotoxic effects of some organophosphorus esters. J Neurochem 1974;23:7859.

14. Johnson MK. Organophosphates and delayed neuropathy--is NTE alive and well? Toxicol Appl Pharmacol 1990;102:385-99.

15. Glynn P. Neural development and neurodegeneration: two faces of neuropathy target esterase. Prog Neurobiol 2000;61:61-74

16. Lotti M. The pathogenesis of organophosphate polyneuropathy. Crit Rev Toxicol 1992;21:465-87.

17. Moretto A, Lotti M, Sabri MI, Spencer PS. Progressive deficit of retrograde axonal transport is associated with the pathogenesis of di-n-butyl dichlorvos axonopathy. J Neurochem 1987;49:1515-22.

18. Kretzschmar D, Hasan G, Sharma S, Heisenberg $\mathrm{M}$, Benzer $\mathrm{S}$. The swisscheese mutant causes glial hyperwrapping and brain degeneration in Drosophila. J Neuroscience 1997;17:7425-32. 


\section{Sažetak}

\section{DEGENERACIJA AKSONA I ESTERAZA POVEZANA S NEUROPATSKIM DJELOVANJEM ORGANOFOSFORNIH SPOJEVA - PREGLED}

Ovim se kratkim pregledom razmatraju nedavna opažanja koja upućuju na mogući mehanizam odgođene neuropatije uzrokovane organofosfatima (engl. organophosphate-induced delayed neuropathy, krat. OPIDN). Za esterazu povezanu s neuropatskim djelovanjem organofosfornih spojeva (engl. neuropathy target esterase, krat. NTE) dokazano je da deacilira fosfatidilkolin (PtdCho) membrane endoplazmatskog retikuluma (ER). Povišene razine PtdCho prisutne su u mozgu swiss cheese/NTE mutanta mušice Drosophila uz abnormalne membranske strukture, degeneraciju aksona i dendrita te gubitak neurona. Slična je vakuolarna patologija zamijećena u mozgu miševa u kojih je obrisan NTE gen u mozgu te koji u starijoj dobi pokazuju kliničke i histopatološke znakove neuropatije koja je slična onoj u običnih miševa kronično tretiranih tri-ortho-krezilfosfatom. Odgođena neuropatija uzrokovana organofosfatima mogla bi biti posljedicom prestanka djelovanja fosfolipaze NTE, što potom uzrokuje zatajenje endoplazmatskog retikuluma i smetnje u prijenosu signala putem aksona te interakcije između glija i aksona.

KLJUČNE RIJEČI: endoplazmatski retikulum, fosfolipid, karbamat, mozak, organofosfat

\section{CORRESPONDING AUTHOR:}

Paul Glynn, Ph. D.

MRC Toxicology Unit, University of Leicester

Hodgkin Building

Lancaster Road, Leicester LE1 9HN, UK.

Email:pg8@le.ac.uk 